\title{
Persuasive way of communicational propaganda
}

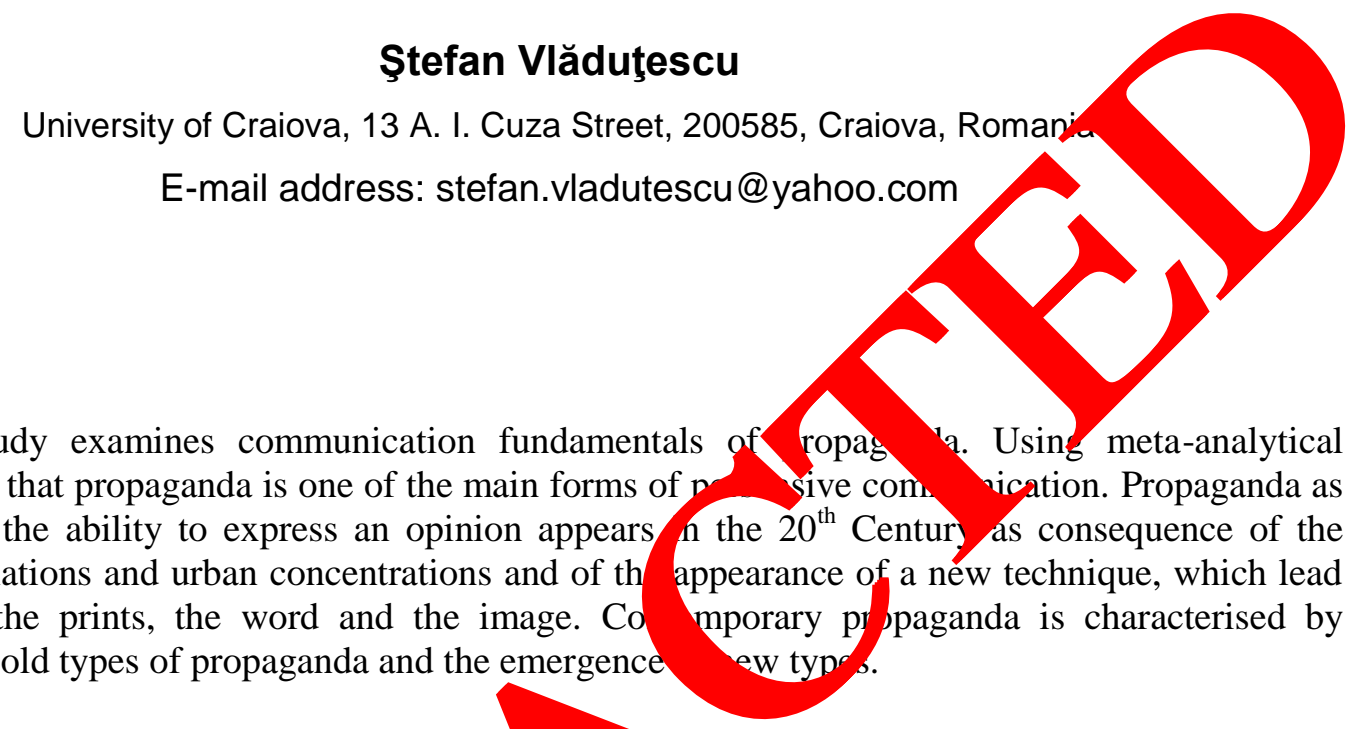

\section{ABSTRACT}

This study examines communication fundamentals method shows that propaganda is one of the main forms of persuasion of the ability to express an opinion appears formation of nations and urban concentrations and of th appearance of a new technique, which lead to spreading the prints, the word and the image. Co mporary pr ppaganda is characterised by improving the old types of propaganda and the emergence

Keywords: persuasive communication; persuasio , n lation ; propaganda

\section{INTRODUCTION}

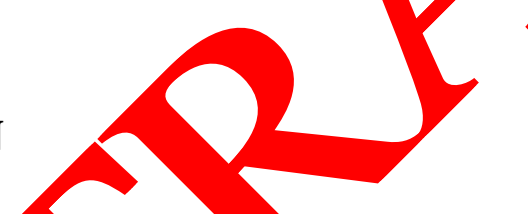

J.-M. Domenach in propas dog "new technique", which is added to social means used to make a cav tri h, mean, which are related to rhetoric, poetry, music, of all traditional forms fine arts. is "technique" uses means which are "made available to it by science" (Dop enack J.-M., 20 , p. 19), "in order to convince and lead the masses". It represents $\%$ ver $11, \mathrm{co}^{2}$ erent technique, which can be systematised to a certain point". According to $\downarrow$ enach, copaganda "is like advertising", by the fact that it also tries "to create form onf irm the opinions" (Domenach, 2004, p. 20). Moreover, it uses part of the neans which th has provided to it. They would be distinguished by the fact that prop nave a political goal, and advertising a commercial goal; the needs or prefere aroused by publicity would target a particular product, while propaganda "suggests imposes believes" and reflexes that often change the psychism, behaviour and even religious or philosophical beliefs. Propaganda influences the fundamental attitude of the human being. According to Domenach (Domenach, 2004, p. 20), political propaganda "is not actually a science that could be concentrated into formulas". One of its characteristics is that it uses the physiological, psychic and unconsciousness mechanisms, of which many are little known. Another one is that its principles originate both in empiricism and in science: advice from experience, general indications. A negative characteristic would be that in the absence of the ideas, talent or audience, this approach is no longer "propaganda, but literature" (Domenach, 2004, p. 2). 
In other words, authentic propaganda is more than just literature. Failure of propaganda leads to pure literature. On the other hand, it borrows major elements of modern science, for directing the soul. Domenach (Domenach, 2004, p. 21) concludes that "propaganda is a way of persuasion of the masses, the style of which changes depending on the situation". It is "and undertaking organised to influence and guide the opinion" (Domenach, 2004, p. 23). According to Ch. U. Larson (Larson, 2003, p. 55), "propaganda is a campaign of mass persuasion".

Although he considers propaganda a way of persuasion, Domenach does not take the distinction all the way to the end, because according to him, the true propagandict is an "individual who wants to convince" (Domenach, 2004, p. 64). As a way of pers asion, is no way for propaganda to also be a way of conviction (Popa, 2010; Arsith Draganese 2011; Hintea, 2013). As examples of confusion concerning propaganda, yo nat other ty ones. Jowett and O`Donnell (Jowett \& O`Donnell, 1992, p. 3) consier that po gar da would be "the same as information, a subcategory of persuas ". Py agand is a subcategory of persuasion, but information is not! Deirdre Johns . Larsd Ch. U., 2003 , p. 398) says that there would be three crucial element in propa da: 1 ceping the secret, manipulating and short-circuiting the logical judgeme th sing emo al arguments and suggestion": Manipulation is not an element of propa nda, a form of persuasion, just as propaganda is!

\section{ROOTS AND EVOLUTION OF PROPAGAN}

The belief of Domenach is that "pr exists since there is political rivalry, meaning since the beginning of the world" ( or chm 2004, p. 18). A sort of propaganda campaign leads Demosthenes againct Philip 1 of Macedon (father of Alexander Macedon). Propaganda action may be called the cursive ffort of Cicero, having Catiline as object.

We need to say it terse yml sls. slogans, images and key-ideas of propaganda are systematically used over h sy our a pandistic consciousness. In his Histoire de la Propagande, Jacques tul conch that "in the political universe, there have been phenomena compara e ( identical) o what we nowadays call propaganda" (Ellul, 1962, p. 5). Among the cor ponents ve would say the proto-propaganda, beautification of books is part thereof. R rated to dictato Iips, the rhetoric of monuments is not always and strictly related to pr gand lthough in some cases, such as Napoleon, Hitler, Stalin and Mao, the rhetoric of mo ents is opagandistic undertaking. Another element of the propagandistic potenc the a ont celebrations, the current national holidays. Life as a feast, pro agand ic life been bread and circuses is specific to Ancient Rome. Here, along with the tity collective life, the germs of propaganda directed outwards, propas a directed inwards and political propaganda are reinforced. Romans particularly appeal to paganda directed inwards as propaganda for integration. In this sense, they operate wi h myths (Vlăduţescu, 2006; Vlăduţescu, 2013; Iorgulescu, 2014). The myths of integration which are now substantiated are: myth of Rome, myth on founding of Rome, myth of founding the historical signification of Rome, myth of the republic, myth of the army as guarantor of Rome.

The further increase of the Roman Empire shall provide force to these myths and shall also have among the supports the propaganda of imposing the myth of Rome and myth of the Roman. The myth of Rome has a perimeter delimited by the following points: the divine origin of Rome, the invincible character of Rome (justification of the defeat for the defeated), 
the democratic feature of Rome, liberating vocation of Rome (Rome frees the nations from tiranies). The constitutive features of the Roman myth are: the cult of the country, courage, virtuosity, devotion, concern for the public wellbeing. The Roman myth is configured and propagated especially by Augustus, Vergilius and Titus Livius (Ellul, 1962, p. 24). On the other hand, the myths for integration found their dissemination via leaflets which circulated in Rome and the celebrations "bread and circuses" where the power of Rome was glorified. So far, lacking the impact allowed to it by the means of communication, propaganda is partial and discontinuous. Propaganda can satisfy its desiderate of continuity and media coverage only along with the effervescence of the French Revolution of 1789 and with that of thr-reign of Napoleon.

The Middle Ages of the proto-propaganda (we say) is presided by the pacy. No propaganda is still directed inwards. With Gregory $\mathrm{XV}$, the concept f p ganda established and propaganda directed outwards is imposed. It may be sa that prop nd is imposed as a propaganda to the outward. The propaganda to th inwar glso nains particularly powerful. Propaganda makes now its first victim nquisit in relies in "Propaganda Fide" on the absence of witnesses, on the abro ation of right of defence and the obligation of proving the innocence. The inquisitio $s$ be an in action to the work of Hitler and Stalin. J. Ellul names this inquisitoriar roce of conviction without evidence a propaganda of terror. It is acquired botb oy he judge $/$ itself, and by the popularisation of the execution: an infamous cross is lates the convict d, follows an auto-dafe with an aura of legend, accompanied by confe ing the guil, as well as by the public retraction of what the inquisitor required. "And it move" is an anti-propagandistic regret.

The first theorist of propaganda is N Mchiavelli. In "The Prince", a few of the techniques of propaganda are exposed: relia ve and chearances ("you must take care of the appearances, because the people indge by a peararce"), installation of beliefs ("to govern means to make people believe") and Intainin a good image.

With Louis XIV (the Sy ing) sropagan a of prestige is typologically imposed. Now, Versailles is the centre of wo th the label is established. The celebrations, feasts, dazzling luxury me to be apagandistic, for they speak about the greatness and glory of the King of $Y$ an

The form of ho propa da of prestige that is directed outwards is called by J. Ellul a sociological pr paganda. This made visible by exporting the prestige (Borowski, 2013; Borowski, 2 4). Th type of propaganda is "the assembly of manifestations by means of which a socie . es to i egrate therein a maximum number of individuals, to unify the behavi of its nbe $s$ according to a model, to diffuse their own life-style to the outside and thus impos nemselves to other groups" (Ellul, 1962, p. 76). The sociological pro life-sty than at the level of the opinion, and one or several political propagandas may be expressed vein.

Duriyg the French Revolution and to Napoleon, based on the doctrine of the sovereignty of the people and national sentiment, propaganda becomes continuous, organised and sustainable. The need for propaganda now appears, and in virtue thereof, the propagandistic approach reaches all areas and tend to form and modify all that is opinion. New myths shape the public space: the myth of the republic, the myth of people's sovereignty, the myth of the citizen and country exaltation.

With Napoleon, the object of propaganda is no longer a doctrine, but a man. Now, by benefiting from the progresses of the pattern, the cult of personality is established. Napoleon 
not only he was not alien to propaganda, he used a military propaganda. He was fully aware of the Organon by means of which leaders endear themselves. He understood well how statesmen are admired. He knew the propagandistic ins and outs by which any government is required to acquire the consent of the public opinion in order to keep the power. As Napoleon showed, it is not enough to do the good to be right, "the ruled still need to be convinced." $\mathrm{He}$ also emphasised that force is based on consent, meaning that governing is nothing without people's consent (Apud Domenach, 2004, p. 18). The Napoleonic propaganda starts from the army and arrives in school, church, it covers the public market. The press reflects the ceremonies, luxury, architecture and movements of the enemies of France: Napolan is always at the centre. This is the model of the state propaganda. Hitler, Stalin, sao wo take a step forward enthralling - or joining - the propaganda for a do ne with t propaganda for a man. It may be noticed that by means of propagan a, es cially $t$ statesmen, dictators, politicians have tried to win and maintain others' attachmes th ir person and to their system of domination and governance.

In the history of propaganda, several eras may be delimite $A_{1} \quad$ Era, $t$ Middle Ages, Modern Era (1789 - 1914) and the contemporary period after tho rst World War). The historical evolution of propaganda is accompanied by a t $\rho$ rical evolt. $A$.

Albert Thibaudet said that in literature, the $20^{\text {th }}$ Cent $y$ beg in 1914. Regarding the propaganda, the $20^{\text {th }}$ Century begins in 1917 , with Len the the the in this century propaganda become total, meaning it draws all means $y$ ito the propagandistic activity, it aims all environments and moves tow ds the entir geographical area of the world. No segment of the public remains outside the entions to influence.

Propaganda had a merit in the establichment on 1 sm and in Hitler's ascent to power. It was decisive in China's transition munism, where it had a more important role than even Mao's troops.

The Leninist propaganda is idoologicall deeply anchored. With Lenin, the communist ideology makes its propagand a, a with $\mathrm{H}$ ler, where the Nazi ideology makes its propaganda. Politics, ideolog d p naganda become one. Propaganda engages the press fully, shapes the cultural dus me nates the school, the army, the church, the architecture, the entire ublic op n (Seceleanu, 2008; Cojocaru, 2010; Cojocaru \& Cojocaru, 2011). Cy uro civilisa on are conquered by propaganda: propaganda is total, propaganda becon polic Shis total propaganda is political propaganda.

J.-M. D menach consio that political propaganda is one of the dominating phenomena the thentury and that the great troubles of the era, the communist revolution and $1 \mathrm{sm}$ col $d$ not be imagined without it. Due to propaganda, Lenin was able to estar the b hevism, and Hitler was able to take the power and achieve in wars the vict ries $n$ ich led 1 straight to the heart of the U.S.S.R. The two have been "two geniuses or p ag of them proclaimed the supremacy of this modern army" (Domenach, 2004, 7).

Tho "shevik propagandistic approach is based on the axiom that "the essential is the agitation as propaganda in all social categories". The Bolsheviks shall create the concept of agitator. Agitators shall be the spearhead of propaganda, road openers for propagandists. Lenin wrote - did not write a page in the history of disinformation: this is debatable. Instead, he has thoroughly inscribed the history of propaganda. In his case, we encounter devices which come into the content of what we call the message principle of frontal noncontradiction: "Tell them what they want to hear" (Apud Volkoff, 1997, p. 71) and "We shall sell them the rope with which they can hang themselves". Propaganda is afraid of the truth. It advances a truth lacking courage. When it seduces, mythicises, when it lies or fantasises, it 
does all this with the fear of truth. Even accidentally it does not want to bring the public on a path of truth. Lenin considered that "telling the truth is a bourgeois prejudice". As such, the truth should not be sought, the objective must be justice. In Russian, "truth" is designated by two terms: "istina" is the truth considered in the contrariety relation with the lie, and pravda is the truth with the meaning of justice. Pravda, the newspaper founded by Lenin did not claim to tell the truth, but that it established the justice. The Leninist sophism of justice is to capitalise the more pronounced relativism of justice to the detriment of the relativism of truth. There may be absolute truth (e.g. mathematical truths), but there is no absolute justice. In the dialogue Euthyphron, Plato showed that in what concerns the justice and rightfulness thare is no unit of measurement. Lenin thought that since people naively become attach a to ho $\mathrm{V}$ words such as truth and justice, they must be used to please them ("to hear wh they want hear"). He considers that, taking into account the fact that the class fight $i$ con cous, the propaganda must also be continuous (Siminică \& Traistaru, 2013; Traist ru \& Avra 201 4). The goal of propaganda must be the permanent indoctrination of th nasse The as is of propaganda were the agitators.

The Hitlerite propagandistic undertaking is established ased on con ction that propaganda brings the power and makes world dominatic ible. If $\mathrm{m}$ and Stalin illustrate a model of a peacetime propaganda, Goebbel the ce of war propaganda. Vladimir Volkoff characterises the latter as a "great trib anc f the wo nd skilful user of the radio", "a propagandist whom constantly and cynical y used the lie" (Volkoff, 1997, p. 63).

Goebbels ("the little doctor") is assigned witl the apotheg" "Propaganda has nothing in common with the truth anymore", because "a lie i ated a th usand times remains a lie, a lie repeated a million times becomes truth" (Apud V ., 1997, p. 63). Let us notice here the consciousness of applying the prind repetition in propaganda. After he notices the role of the lie at Goebbels, Volkoff drau the an that in reality, it was not the lie that prevailed in his program, but the erupt 1 of Volcanic passions, instigation of anger explosions. Above all, "the lit a o tor" re sd on cold seduction. By capitalising the emotional side, the masses y set $j$ motion, heir hatred and desperation were organised with a cold calculation. A rove of propanda was not to be intelligent, but to ensure success, cause the message transmitted to the masses generally does not matter with 1 th vpe of per aasion, it does not import the transmitted theory, but something beyon ' it. adhes of the masses. In order to get the consent of the masses, the most efficient means are tho based on appearance, not on truth. The propagandistic adhesion is anly o ined by operations of seduction and appeal to myths (let us recall here the Nazi myt the A an being, the myth of the Roman, the myth of the French revolut ry cit in 1789), and in the subsidiary, by lie and fiction. In any case, in pro agand the lic erves the seduction and fiction serves the myth. "The essence of pro ${ }_{1}$ no Goebbels, is to gain the beings for an idea, in an intimate and alive way, so tha v wourd end up giving themselves in to it and not being able to give it up anymore" (Apud Vo fr, 1997, p . 63).

We snould note that Hitlerite propaganda had two stages: uprooting and replanting. Uprooting was done by operations of seduction and establishment in the environment of the myth of Germany and Aryanism, and replanting was done by means of the lie and fiction, implanting the new ideas of fighter. The uprooting arsenal consisted of parades, flags, drums, torches, Hitlerite salute, shouts of Sieg Heil chanted out loud. The implantation toolkit consisted of providing social axioms: ethnic cleansing, fight to the end for a Great Germany, the sacrifice for the glory of the Reich. 


\section{CONCLUSION}

In contemporary, propaganda's specificity is the Globalisation of sending its message through media-type communications. Horizontal propaganda is characterised by dimming the contrast between propagandist and target-group. One may say it is based on the equality of group members. Every individual makes propaganda and is object of propaganda, within a global process of influence, support, promotion and exposure to the actions of others.

\section{ACKNOWLEDGMENT}

This work was partially supported by the grant number 33C/2014, awarded in the internal grat mpetition the University of Craiova.

\section{References}

[1] J. A. C. Brown (1963). Techniques of persuasion: From pro anda to brainwashing (Vol. 604). Middlesex: Penguin Books

[2] Andrzej Borowski, International Letters of Sociq and Humanistic ,ciences 14 (2014) 7-17.

[3] Jason L. Powell, International Letters of Social a Humani fic Sciences 16(2) (2014) 177-183.

[4] Stefan Cojocaru, Constantin Bragaru, Tra pytr peview of Administrative sciences 35E (2012) 62-77.

[5] Ş. Buzărnescu (1996). Socio ogia iniei pr. Vice. Bucureşti : Editura Didactică şi Pedagogică.

[6] Hentea Călin (2012) cncıclop propagandei româneşti. Bucureşti: Editura Adevărul.

[7] A. Seceleanu $(20$ 8). municared politică în spaţiul mediatic. Editura Fundaţia Andrei Şaguna.

[8] Daniela C Jocan Antonio andu, Stefan Cojocaru, Journal for the Study of Religions and Idho ies 2o(2011) 65-83.

[9] Sily-Neacşे 005 Sistemul informaţional statistic în învăţământul românesc după 990. d. Fund Univ. Pentru Toţi.

[10] Oan, Analele Universităţii din Craiova. Seria Ştiinţe Filologice. L. vistică 1-2 (2009) 272-278.

[11] L. Op ca, C. Vladescu, V. Astărăstoae, S. G. Scîntee (2010). Aspecte etice ale inegalităţilor sociale în ingrijirile medicale. Revista Română de Bioetică.

[12] Andrzej Borowski, International Letters of Social and Humanistic Sciences 14 (2014) $33-41$.

[13] M. Colhon (2013). Automatic Lexical Alignment between Syntactically Weak Related Languages. Application for English and Romanian. In Computational Collective Intelligence. Technologies and Applications (pp. 266-275). Springer Berlin Heidelberg. 
[14] J.-E. Combs, D. Nimmo (1992). The New Propaganda. The Dictatorship of Palaver in Contemporary Politics. New-York: Longman.

[15] Marian Siminică, Aurelia Traistaru, International Journal of Education and Research 1(12) 2013.

[16] A. Traistaru, M. Avram, International Letters of Social and Humanistic Sciences 13 (2014) 79-88.

[17] Andrzej Borowski, International Letters of Social and Humanistic Sciences 4 (2013) 70-74.

[18] M. Nowicka-Skowron, S. M. Radu (2014). The information and company' innovative creative activity under the current conditions of the market economy. Com vication Neutrosophic Routes.

[19] Doina Mihaela Popa, Anuarul Universităţii" Petre Andrei” Iaşi ccicu Drept, diinţe Economice, Ştiinţe Politice 05 (2010) 243-253.

[20] A. Borowski, International Letters of Social and Humani Sciences 1-168

[21] J.-M. Domenach (2004). Propaganda politică. Iaşi: Fo ura h utul European.

[22] J. Ellul (1962). Histoire de la Propagande. Paris Armand Colin.

[23] Alexandra Iorgulescu, International Letters of cial and Humanistic Sciences 17 (2014) 80-84.

[24] Daniela Cojocaru, Stefan Cojocaru, $R$ 144-158.

[25] Ionel Narita, Analele Universitătii Spiru vret. Seria Jurnalism 14(2) (2013) 33-41.

[26] Andrezj Borowski, Intern lona etters of Gocial and Humanistic Sciences 2 (2014) 110-121.

[27] Sandu Antonio (20\%). Metoa cercetare in stiinta comunicarii. Editura Lumen.

[28] G. S. Jowett, V J'D ell, (Eds.). (2011). Propaganda \& persuasion. Sage.

[29] C. U. Larso A (2003). Pen siunea. Iaşi: Editura Polirom.

[30] Stefan iocary Revista de Cercetare şi Intervenţie socială 20 (2008) 42-48.

[31] Doina Mì จ Popa Anuarul Universităţii" Petre Andrei” Iaşi-Fascicula Drept, Ştiinţe coo nice, ş, politice 08 (2011) 395-402.

[2. um ita Rosca (2004). Producţia textului jurnalistic. Editura Polirom, Iaşi.

[33] M Tina Cerban, Annales Universitatis Apulensis. Series Philologica I(2) (2008) 173

[34] M. Arsith, O. Draganescu (2011). Communication and Organizational Culture. EIRP Proceedings.

[35] A. Otovescu, M. A. Frăsie, G. Motoi, D. Otovescu (2011) Criza mondială. Editura Pro Universitaria, Bucureşti.

[36] C.-F. Popescu (2002). Dicţionar de journalism. Bucureşti: Editura Tritonic. Tragedy. 
[37] Alexandra Iorgulescu (2014). Neutrosophic Inflexions in Seneca's Communication Neutrosophic Routes.

[38] B. M. Dascălu (2014). Echivocul imagologic în Caietele lui Emil Cioran. Studii de Ştiinţă şi Cultură.

[39] Daniela Gîfu (2014). Humor in the Religious Discourse: between Paradoxism and Neutrosophy. Communication Neutrosophic Routes.

[40] Cătălina Maria Georgescu (2009). Migraţia forţei de muncă şi securitatea statelor în spatial european în "Actele Simpozionului Internaţional Politica de vecinătate spirit european".

[41] Andrezj Borowski, International Letters of Social and Humanistic Sciences 2013) 69-74.

[42] V. Volkoff (1997). Tratat de dezinformare. Bucureşti: Editura

[43] Aurelia Traistaru (2013). Consolidation of the green marke austerity period. Jokull.

[44] Calin Emilian Hintea, Revista de Cercetare şi Intery

[45] Felicia Cornelia Macarie, Călin Hinţea, Cristina Nora, Transylva in Review of Administrative Sciences 32E (2011) 146-156.

[46] Janusz Grabara, Vladimir Modrak, Ioan Consta nima, I ternational Letters of Social and Humanistic Sciences 15 (2014) 148-

[47] Stefan Cojocaru, Journal for the Study thy and Ideologies 5(13) (2010) 32-38.

[48] O. Bunea, D. Cojocaru, S. Cojocaru (201 Family strengthening program. Evaluation report. Social Research Rer orts

[49] Moraru Mihai (1997). Re otii Moxcurii et Philologiae. Editura Fundației Culturale Române.

[50] P. Bajdor, I. Gra du ournal of dies in Social Sciences 7(2) (2014).

[51] Cristina Gay ovici, L Oprea, Revista Romana De Bioetica 11(3) (2013).

[52] Stefan C jocar Journal f $r$ the Study of Religions and Ideologies 4(10) (2010) 36-48.

[53] Ioan Hor 'ana Pa ea (2007). Europe from Exclusive Borders to Inclusive F iers. L limes.

Iason L. Powel, International Letters of Social and Humanistic Sciences 7 (2014)

[55] Mà inz Strechie (2014). Communication as the Main Source of Neutrality in Ancient Rome Communication Neutrosophic Routes.

[56] A. Gorun, D. R. Mateiu, H. T. Gorun (2003). Elemente de Administraţie Publică, Jurisprudenţă şi Drept administrativ. Cluj-Napoca.

[57] Goran Rajović, Jelisavka Bulatović, International Letters of Social and Humanistic Sciences 15(2) (2014) 125-137.

[58] Florica Iuhaş (2012). Mass Media Anthropology: a Post-modern Field of Research. Advanced Research in Scientific Areas. 
[59] Nirmal Kumar Betchoo, International Letters of Social and Humanistic Sciences 16(1) (2014) 39-48.

[60] Ştefan Viorel Ghenea (2008). Relativism versus Scientific Rationality. Analele Universităţii de Vest din Timişoara.

[61] Jason L. Powell, International Letters of Social and Humanistic Sciences 16(2) (2014) 177-183.

[62] Anca Parmena Olimid (2013). Political Change and Democracy Building in Eastern Europe. Rethinking the Theoretical Approaches of Transition. Revista de Stiin Politice.

[63] Jacek Tittenbrun, International Letters of Social and Humanistic Sciences 26-48.

[64] Stefan Cojocaru (2010). Evaluarea programelor de asistenta so la. Ia - Poliro

[65] Jason L. Powell, International Letters of Social and Human omosci os 17(1) (2014) 1-60.

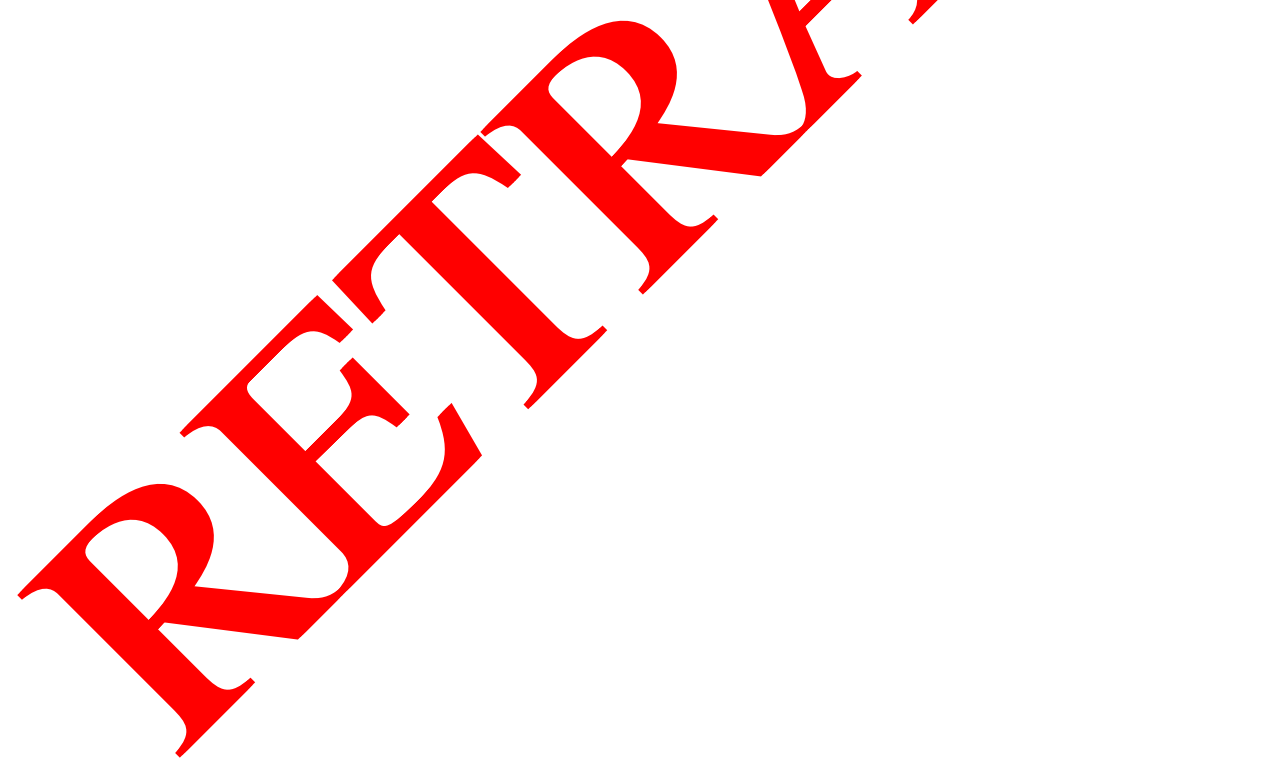

